\title{
KAJIAN INTERAKSI OBAT PADA PASIEN STROK DI RUMAH SAKIT PUSAT OTAK NASIONAL
}

\section{(STUDY OF DRUG INTERACTION IN STROKE PATIENTS AT RUMAH SAKIT PUSAT OTAK NASIONAL)}

\author{
PUTU RIKA VERYANTI ${ }^{1}$, ISNI SAFIRA $^{1}$ \\ ${ }^{1}$ Fakultas Farmasi Institut Sains dan Teknologi Nasional
}

\begin{abstract}
Abstrak: Strok merupakan penyakit pembuluh darah otak yang ditandai dengan kematian jaringan akibat berkurangnya aliran darah dan oksigen ke otak. Strok memiliki berbagai faktor resiko dan komplikasi yang menyebabkan pasien mendapatkan banyak pengobatan (polifarmasi). Polifarmasi berpotensi menimbulkan kejadian interaksi obat yang dapat merugikan pasien. Tujuan dari penelitian ini adalah untuk mengetahui gambaran interaksi obat aktual yang terjadi pada pasien strok di Rumah Sakit Pusat Otak Nasional. Penelitian ini merupakan penelitian observasional yang dilakukan secara prospektif dari bulan Mei-juli 2016 di ruang Stroke Care Unit (SCU) Rumah Sakit Pusat Otak Nasional. Dalam pengambilan sampel digunakan teknik purposive sampling dan diperoleh 80 pasien yang memenuhi kriteria inklusi dan eksklusi. Hasil penelitian menunjukkan bahwa potensi interaksi obat yang terjadi pada pasien strok di Rumah Sakit Pusat Otak Nasional sebanyak 178 kejadian, namun interaksi obat aktual yang terjadi hanya 3 kejadian. Tiga kejadian interaksi obat tersebut dialami oleh 5 pasien $(6,25 \%)$ dimana obat-obat yang berinteraksi tersebut adalah Digoksin dengan Kaptopril (1,25\%), Phenitoin dengan Nimodipin (2,5\%) dan Kaptopril dengan Furosemid (2,5\%). Penanganan yang tepat pada kejadian interaksi obat aktual telah dilakukan oleh klinisi di Rumah Sakit Pusat Otak Nasional sehingga pasien mendapatkan efek terapi yang optimal.
\end{abstract}

Kata kunci: interaksi obat, rumah sakit pusat otak nasional, strok.

\begin{abstract}
Stroke is a cerebral vascular disease characterized by tissue death due to reduced blood flow and oxygen to the brain. Patient suffered from stroke may take many medication (polypharmacy) which may increase the risk of drug. The purpose of this study was to describe the actual drug interactions that occur in stroke patients at Rumah Sakit Pusat Otak Nasional. This study was an observational study conducted prospectively from May-July 2016 at the Stroke Care Unit (SCU) at Rumah Sakit Pusat Otak Nasional. We used purposive sampling technique and obtained 80 patients who appropriate to the inclusion and exclusion criteria. The results showed that the potential drug interactions that occurred in stroke patients at Rumah Sakit Pusat Otak Nasional were 178 events, but the actual drug interactions that occurred were only 3 events. The three occurrences of drug interactions were experienced by 5 patients $(6.25 \%)$. The interacting drugs were Digoxin with Captopril (1.25\%), Phenytoin with Nimodipine (2.5\%) and Captopril with Furosemide (2.5\%). Proper treatment of the actual occurrence of drug interactions has been carried out by the clinician, so that patients get the optimal therapeutic effect.
\end{abstract}

Keywords: Drug interaction, stroke, rumah sakit pusat otak nasional.

\section{PENDAHULUAN}

Strok merupakan penyakit pembuluh darah otak yang terjadi akibat tersumbat atau pecahnya pembuluh darah yang mengakibatkan terputusnya aliran darah ke otak. Terputusnya aliran darah ini menyebabkan pasokan nutrisi dan oksigen ke otak menjadi berkurang sehingga dapat menyebabkan kematian (Sacco R.L, Kasner S.E, et al., 2013). Dalam 5 tahun terakhir, prevalensi strok di Indonesia mengalami peningkatan dari
7\% pada tahun 2013 menjadi 10,9\% pada tahun 2018 (Balitbang Kemenkes RI, 2018).

Meningkatnya prevalensi strok di Indonesia dapat disebabkan oleh beberapa faktor resiko yang dimiliki oleh masyarakat. Menurut Riyadina dan Rahajeng (2013) determinan utama penyakit strok adalah hipertensi, diabetes melitus dan penyakit jantung koroner. Pasien hipertensi beresiko mengalami strok $4 \mathrm{x}$ lebih besar dibandingkan dengan orang sehat. Sedangkan diabetes melitus dan penyakit jantung koroner masing-masing memiliki resiko 3 dan 2 kali lebih

\footnotetext{
•correspondence email: rika veryanti@istn.ac.id
} 
besar (Riyadina W dan Rahajeng E, 2013). Disamping faktor resiko, strok juga memiliki komplikasi yang beragam, seperti udema pada otak, infeksi saluran pernafasan, pneumonia, emboli paru, deep vein trombosis, komplikasi ortophedik, decubitus dll (Bovim M.R, Askim T, et al., 2016. Bustamante A, Giralt D, et al.,2017). Beragamnya faktor resiko dan komplikasi yang terjadi pada pasien strok mengakibatkan pasien membutuhkan pengobatan yang banyak (polifarmasi) (Zulkarnaini A dan Martini R.D., 2019).

Polifarmasi adalah penggunaan obat $\geq 5$ dalam sehari. Polifarmasi dapat meningkatkan potensi interaksi obat yang dapat merugikan pasien. Interaksi obat merupakan modifikasi efek obat yang diakibatkan oleh obat lain sehingga efektivitas dan toksisitas dari obat tersebut berubah (Stockley, I.H, 2010). Penelitian yang dilakukan Khalida H (2015) menunjukkan bahwa potensi interaksi obat pada peresepan dengan jumlah obat $\geq 5$ terjadi sebanyak $85,80 \%$ (Khalida $\mathrm{H}, 2015)$. Dampak interaksi obat yang merugikan pasien diantaranya adalah peningkatan biaya dan lama waktu pengobatan, penurunan efektivitas terapi, meningkatnya reaksi obat yang tidak diinginkan pada pasien bahkan dapat berdampak pada kematian (Bukhari S., 2017).

Berdasarkan uraian di atas maka dilakukan penelitian tentang kajian interaksi obat pada pasien strok di Rumah Sakit Pusat Otak Nasional. Penelitian ini bertujuan untuk mengetahui gambaran kejadian interaksi obat aktual pada pasien strok di Rumah Sakit Pusat Otak Nasional. Rumah Sakit Pusat Otak Nasional merupakan rumah sakit rujukan dalam penanganan kasus gangguan otak dan sistem persyarafan (neurologi).

\section{METODOLOGI PENELITIAN}

Desain penelitian. Penelitian ini merupakan penelitian observasional yang dilakukan secara prospektif. Pasien strok yang ada di ruang Strok Care Unit (SCU) diikuti dan diamati perkembangan pengobatannya dari awal masuk sampai keluar rumah sakit dalam periode Mei-Juli 2016.

Waktu dan Tempat Penelitian. Pengambilan data di lakukan di ruang Stroke Care Unit (SCU) Rumah Sakit Pusat Otak Nasional selama 3 bulan dari bulan Mei sampai Juli 2016.
Populasi dan Sampel. Populasi dalam penelitian ini adalah seluruh pasien yang didiagnosa strok di Rumah Sakit Pusat Otak Nasional. Sedangkan sampel yang digunakan adalah pasien yang memenuhi kriteria inklusi seperti didiagnosa strok dan mendapatkan pengobatan $\geq 5$ jenis. Pasien dengan terminaly ill dan memiliki data rekam medis yang tidak lengkap dieksklusi dari penelitian ini. Jumlah sampel yang memenuhi kriteria inklusi dan eksklusi adalah 80 pasien.

Analisis Data. Data yang diperoleh berupa demografi pasien (usia, jenis kelamin dan jenis strok) serta data pengobatan pasien. Data tersebut selanjutnya ditabulasi dan ditampilkan pada tabel dalam bentuk persentase. Obat-obat yang digunakan pasien dibuatkan profil, selanjutnya dikelompokkan berdasarkan kelas terapi. Pengkajian interaksi obat baik yang potensial maupun aktual dilakukan dengan menggunakan literatur Stokley's Drug Interaction. Interaksi obat aktual diidentifikasi dengan cara memonitoring langsung keadaan pasien, parameter-parameter yang perlu dimonitoring ditentukan berdasarkan potensi mekanisme interaksi obat yang terjadi. Apabila dalam pemantauan parameter tersebut pasien mengalami ketidak-normalam nilai/hasil, maka pasien disebut mengalami interaksi obat aktual. Bila tidak, obat-obat yang diberikan hanya berpotensi mengalami interaksi (bukan interaksi obat aktual). Hasil pengamatan interaksi obat aktual ditampilkan dalam bentuk persentase dengan membandingkan jumlah pasien yang mengalami interaksi obat dengan total sampel.

\section{HASIL DAN PEMBAHASAN}

Demografi Pasien. Dari 80 pasien strok di Rumah Sakit Pusat Otak Nasional diketahui bahwa strok lebih banyak diderita oleh pasien dengan jenis kelamin laki-laki yaitu sebesar 59\%. Salah satu penyebabnya adalah perbedaan kadar hormon estrogen antara laki-laki dan perempuan. Kadar hormon estrogen pada laki-laki tidak sebanyak pada perempuan. Hormon estrogen dapat berfungsi untuk menurunkan LDL dan meningkatkan kadar HDL dalam darah sehingga dapat mencegah terjadinya atherosclerosis (Ghani L, Mihardja L.K, dkk, 2016). Faktor penyebab lainnya adalah kebiasaan merokok yang lebih banyak pada laki-laki dibandingkan perempuan. Nikotin yang masuk ke dalam tubuh dapat membuat dinding pembuluh darah menjadi tidak licin lagi sehingga membuat plak-plak seperti 
kolesterol mudah menempel dan menyumbat pembuluh darah. Perokok aktif berisiko 2-4 kali terkena strok dibanding yang tidak pernah merokok (Ghani L, Mihardja L.K, dkk, 2016).

Berdasarkan usia, dalam penelitian ini strok paling banyak dialami oleh pasien di atas 65 tahun $(46,25 \%)$. Menurut Perhimpunan Dokter Spesialis Saraf Indonesia (PERDOSSI) tahun 2011, salah satu faktor resiko yang tidak dapat dimodifikasi untuk penyakit strok adalah bertambahnya usia. Peningkatan umur memiliki potensi untuk meningkatkan kerentanan seseorang untuk menderita penyakit, khususnya penyakit degeneratif. Hal ini berhubungan erat dengan penurunan fungsi organ tubuh akibat penuaan. Lansia mudah terkena strok karena pembuluh darah menjadi tidak elastis terutama bagian endotel yang mengalami penebalan pada bagian intima, sehingga mengakibatkan lumen pembuluh darah semakin sempit dan berdampak pada tekanan aliran darah, yang dapat memperbesar resiko terjadinya perdarahan pada pembuluh darah otak (PERDOSSI, 2011). Hal tersebut sejalan dengan penelitian yang dilakukan Alexander (2011) bahwa kejadian strok akan semakin meningkat dua kali lipat setelah melewati 55 tahun (Alexander L.L, 2011).

Kejadian strok hemoragik pada penelitian ini memiliki proporsi lebih besar dibandingkan dengan strok iskhemik. Pasien strok yang memiliki riwayat hipertensi yang tidak terkontrol dapat meningkatkan resiko strok hemoragik (Balitbang Kemenkes RI, 2018). Selain itu strok hemoragik juga diakibatkan oleh manajemen stres yang buruk dan pola hidup yang tidak sehat seperti merokok, makan makanan tinggi lemak, minum alkohol, dan tidur tidak teratur. Tingkat morbiditas dan mortalitas strok hemoragik lebih tinggi dibandinghkan stok iskhemik sehingga pasien dengan strok hemoragik lebih banyak dirawat diruang intensif (Balitbang Kemenkes RI, 2018). Data demografi pasien selengkapnya ditampilkan pada tabel 1 .

\begin{tabular}{lcc} 
Tabel 1. Demografi Pasien Strok di Rumah Sakit Pusat Otak Nasional \\
\cline { 2 - 3 } \multicolumn{1}{c}{ Variabel } & Jumlah Pasien & Presentase (\%) \\
\hline Jenis Kelamin & 47 & 59 \\
Laki-laki & 33 & 41 \\
Perempuan & & \\
Jenis Stroke & 38 & 47.5 \\
Stroke Iskemik & 42 & 52.5 \\
Stroke Hemoragik & & \\
Usia & 5 & 6.25 \\
26-35 tahun & 11 & 13.75 \\
36-45 tahun & 12 & 15 \\
46-55 tahun & 15 & 18.75 \\
56-65 tahun & 37 & 46.25 \\
Lebih dari 65 tahun &
\end{tabular}

Gambaran Penggunaan Obat Pasien. Tabel 2 menunjukkan 10 besar obat-obatan yang paling sering diresepkan pada pasien strok di Rumah Sakit Pusat Otak Nasional. Berdasarkan tabel, obat yang paling sering diresepkan adalah Amlodipin. Amlodipin termasuk obat antihipertensi golongan penghambat saluran kalsium (Calcium Channel Blocker) yang direkomendasikan PERDOSSI dalam penatalaksanaan hipertensi pada pasien strok. Hasil yang sama juga ditunjukkan oleh penelitian yang dilakukan oleh Putri (2014) dimana Amlodipin merupakan obat yang paling sering diresepkan pada pasien strok. Amlodipin diketahui dapat memberikan efek perlindungan yang baik bagi pasien strok yaitu menghambat influx kalsium sehingga terjadi relaksasi pada otot.
Selain itu, obat ini merupakan agen terapetik yang efektif dalam penurunan tekanan darah sistol dan diastol dibandingkan obat antihipertensi lain pada pasien strok (Putri L.E, 2014).

Obat selanjutnya adalah Ranitidin. Ranitidin merupakan obat golongan Antagonis Reseptor $\mathrm{H}_{2}\left(\mathrm{AH}_{2}\right)$, yang bekerja menghambat reseptor histamin $\mathrm{H}_{2}$ secara selektif dan reversibel. Ranitidin biasanya diberikan sebagai terapi preventif stres ulcer pada pasien stok yang menjalani perawatan (Alhazzani W, Alshamsi F, Belley-Cote E, et al.,2018). Acetylsistein telah digunakan secara klinis selama lebih dari 30 tahun dan bekerja secara primer sebagai mukolitik dan antidot pada manajemen terapi keracunan paracetamol. Selain itu acetylsistein adalah senyawa yang mengandung tiol dengan efek 
antioksidan dan anti inflamasi (Dewi R.T.K, Siregar P, dkk., 2015).

Asam Traneksamat adalah obat golongan hemostatik sistemik yang bekerja mengurangi perdarahan dengan cara menghambat aktivasi plasminogen menjadi plasmin pada pambekuan darah. Karena plasmin berfungsi mendegradasi fibrin, maka asam traneksamat bekerja menghambat degradasi fibrin, yang berujung pada meningkatnya aktivitas pembekuan darah. Sedangkan Tramadol merupakan obat analgesik yang bekerja secara sentral, bersifat agonis opioid. Pasien diruang SCU diberikan terapi tramadol karena keluhan nyeri kepala hebat yang terjadi salah satunya karena peningkatan tekanan intrakranial yang disebabkan adanya pendarahan atau pembengkakan pada otak.

Menurut Perhimpunan Dokter Spesialis Saraf Indonesia (2011), manitol telah menjadi salah satu pilihan utama dalam penanganan peningkatan TIK (Tekanan Intrakranial) yang cepat, cukup efektif, dan aman (PERDOSSI, 2011). Penggunaan parasetamol pada pasien strok karena strok juga disertai demam (hipertermi) yang ditandai dengan peningkatan suhu tubuh mencapai $37,5^{\circ} \mathrm{C}$ setelah 48 jam onset strok.

Laktulosa adalah obat yang digunakan untuk mengatasi konstipasi atau sulit buang air besar. Obat ini bekerja dengan meningkatkan tekanan osmotik pada lumen saluran gastrointestinal,sehingga menngkatkan kadar cairan dalam usus dan membuat feses lebih lunak. Mekanisme kerja metformin menambah up-take (utilasi) glukosa diperifer dengan meningkatkan sensitifitas jaringan terhadap insulin, menekan produksi glukosa oleh hati, menurunkan oksidasi fatty acid dan meningkatkan pemakaian glukosa dalam usus melalui proses non oksidatif (American Diabetes Association, 2015).

Tabel 2. Sepuluh Besar Obat yang Paling sering Diresepkan

\begin{tabular}{clcc}
\hline No. & Nama Obat & $\begin{array}{c}\text { Frekuensi } \\
(\mathbf{n})\end{array}$ & $\begin{array}{c}\text { Presentase } \\
(\boldsymbol{\%})\end{array}$ \\
\hline 1 & Amlodipin & 57 & 6 \\
2 & Ranitidin & 55 & 5.4 \\
3 & Asetilsistein & 52 & 5.1 \\
4 & Asam & 42 & 4.3 \\
5 & Traneksamat & & \\
6 & Tramadol & 42 & 4.3 \\
7 & Pannitol & 40 & 4 \\
8 & Laktulosa & 36 & 3.8 \\
9 & Metformin & 36 & 3.7 \\
10 & Kaptopril & 36 & 3.7 \\
\hline
\end{tabular}

Kaptopril merupakan obat antihipertensi golongan Penghambat Angiotensin Converting Enzyme (ACE Inhibitor) yang menghambat secara kompetitif pembentukan angiotensi II dari prekursor angiotensin I yang inaktif, yang terdapat pada darah, pembuluh darah, ginjal, jantung, kelenjar adrenal, dan otak (PERDOSSI, 2011).

Potensi Interaksi Obat pada Pasien. Sebanyak 69 pasien dari 80 sampel dalam penelitian ini berpotensi mengalami interaksi obat. Secara teori, dengan penelusuran literatur diketahui bahwa dari 69 pasien tersebut berpotensi mengalami 178 kejadian interaksi obat. Hal ini dapat dilihat pada tabel 3 dan 4 . Tabel 4 juga menunjukkan bahwa potensi interaksi obat dapat terjadi secara farmakokinetik $(58,4 \%), \quad$ farmakodinamik $(33,2 \%)$ ataupun yang mekanisme interaksinya belum diketahui $(8,4 \%)$. Contoh obat-obat yang berinteraksi secara farmakokinetik diantaranya adalah phenitoin dengan deksametason serta digoksin dengan omeprazol. Phenitoin merupakan inducer enzim di hati, sehingga dapat meningkatkan metabolisme dan klirens dari deksametason. Interaksi ini berpotensi menurunkan kadar dan efek deksametason pada pasien. Mekanisme interaksi obat tersebut merupakan jenis interaksi farmakokinetik pada tahap metabolisme. Sedangkan digoksin dan omeprazol berpotensi mengalami interaksi obat secara farmakokinetik tahap absorbsi. Omeprazol dapat meningkatkan $\mathrm{pH}$ lambung sehingga digoksin yang merupakan basa lemah akan berada dalam bentuk tidak terionkan sehingga mudah untuk diabsorbsi. Peningkatan bioavaibilitas digoksin berpotensi menyebabkkan toksisitas digitalis. Efek toksik digoksin seperti gejala takikardia pada pasien perlu dimonitoring secara ketat (Stockley, I.H., 2010).

Contoh obat yang berinteraksi secara farmakodinamik pada penelitian ini adalah pemberian bersama antara salbutamol dan karvedilol. Karvedilol merupakan obat golongan penghambat reseptor beta yang tidak selektif sehingga dapat menghambat reseptor beta 1 dan beta 2 . Penghambatan pada reseptor beta 2 dapat menyebabkan bronkokonstriksi. Hal ini bersifat antagonis terhadap salbutamol yang merupakan bronkodilator (beta 2 agonis). Bila kedua obat ini diberi secara bersama, maka keadaan sesak atau nilai respiratory rate pasien perlu dipantau (Stockley, I.H., 2010). 
Tabel 3. Interaksi Obat Potensial pada Pasien Strok

\begin{tabular}{cccc}
\hline No. & Potensi Interaksi & Jumlah Pasien & Persentase (\%) \\
\hline 1 & Terjadi Interaksi & 69 & 86.25 \\
2 & Tidak Terjadi Interaksi & 11 & 13.75 \\
& Total & $\mathbf{8 0}$ & $\mathbf{1 0 0}$ \\
\hline
\end{tabular}

Tabel 4. Klasifikasi Interaksi Obat Potensial Berdasarkan Mekanisme Interaksi

\begin{tabular}{cccc}
\hline No. & Mekanisme Interaksi & Jumlah Kasus & Presentase (\%) \\
\hline 1 & Farmakokinetik & 104 & 58.4 \\
2 & Farmakodinamik & 59 & 33.2 \\
3 & Belum Diketahui & 15 & 8.4 \\
& Total & 178 & 100 \\
\hline
\end{tabular}

Tabel 5 menampilkan sepuluh besar obatobatan yang berpotensi mengalami interaksi. Ranitidin dan metformin bila dikonsumsi secara bersamaan dapat menurunkan eksresi metformin di ginjal, akibatnya kadar metformin di dalam darah meningkat sehingga dapat menimbulkan resiko hipoglikemia. Ranitidin juga dapat menunda penyerapan Parasetamol dengan mengurangi pengosongan lambung. Akibatnya kadar parasetamol dalam darah menurun dan mengurangi efek farmakologinya. Ondansentron (5HT3-receptor antagonist) dapat menurunkan efek antinyeri tramadol karena serotonin $(5-\mathrm{HT})$ diperkirakan mempengaruhi respon nyeri melalui reseptor presinaptik 5-HT3 di spinal dorsal horn. Akibatnya pasien yang mendapatkan terapi kedua obat ini secara bersamaan memerlukan 26-35\% lebih banyak tramadol (Stockley, I.H., 2010).

Obat lain yang berinteraksi adalah Ranitidin dan Vit B12. Ranitidin menurunkan absorbsi vitamin B12 dengan menurunkan produksi asam lambung. Asam lambung diperlukan untuk membantu melepaskan vitamin
B12 dari sumber protein, akibatnya kadar vitamin B12 dalam tubuh menurun. Metoklopramid meningkatkan kadar puncak plasma dan menyerapan dari parasetamol. Akibatnya efek dan kadar parasetamol dalam darah meningkat sehingga meningkatkan resiko toksisitas dan efek samping parasetamol. Asetosal dan Klopidogrel bila dikonsumsi bersamaan dapat meningkatkan resiko perdarahan tetapi mekanismenya belum diketahui. Amlodipin menghambat sitokrom P450 isoenzim CYP3A4 yang memetabolisme simvastatin sehingga kadar simvastatin dalam darah meningkat. Akibatnya dapat meningkatkan resiko toksisitas dan efek samping simvastatin. Sukralfat dapat menghambat penyerapan phenitoin pada saluran pencernaan sehingga kadar metformin dalam darah menurun. Phenitoin dapat mempercepat metabolisme ondansentron sehingga efek antiemetik ondansentron berkurang. Levofloksasin dan Ondansentron bila dikonsumsi secara bersamaan dapat meningkatkan QTc interval sehingga dapat meningkatkan resiko aritmia ventrikel (Stockley, I.H., 2010).

Tabel 5. Sepuluh Besar Obat-Obatan yang Berpotensi Mengalami Interaksi

\begin{tabular}{clcc}
\hline No. & \multicolumn{1}{c}{ Nama Obat } & Jumlah Kasus & $\begin{array}{c}\text { Persentase } \\
(\mathbf{\%})\end{array}$ \\
\hline 1 & Ranitidin + Metformin & 23 & 13 \\
2 & Ranitidin + Parasetamol & 19 & 10.67 \\
3 & Tramadol + Ondansentron & 18 & 10.11 \\
4 & Ranitidin + Vitamin B12 & 15 & 8.42 \\
5 & Parasetamol + Metoklopramid & 12 & 6.74 \\
6 & Asetosal + Klopidogrel & 6 & 3.37 \\
7 & Amlodipin + Simvastatin & 6 & 3.37 \\
8 & Phenitoin + Sukralfat & 6 & 3.37 \\
9 & Phenitoin + Ondansentron & 6 & 3.37 \\
10 & Levofloksasin + Ondansentron & 6 & 3.37 \\
\hline
\end{tabular}


Interaksi Obat Aktual pada Pasien. Walaupun potensi interaksi obat pada pasien strok pada penelitian ini cukup tinggi, namun interaksi obat aktual hanya terjadi pada 5 pasien $(6,25 \%)$. Satu pasien $(1,25 \%)$ mengalami interaksi antara Digoxin dan Kaptopril, 2 pasien $(2,5 \%)$ mengalami interaksi Phenitoin dan Nimodipin dan 2 pasien lagi $(2,5 \%)$ mengalami interaksi antara Kaptopril dan Furosemid. Rendahnya tingkat kejadian interaksi obat aktual ini disebabkan oleh usaha pencegahan yang telah dilakukan sebelumnya oleh tenaga medis yang ada di SCU Rumah Sakit Pusat Otak Nasional. Usaha-usaha pencegahan tersebut misalnya apoteker melakukan pengaturan minum obat pasien sehingga obat-obat yang berpotensi mengalami interaksi tidak diminum secara bersama, disamping itu apoteker juga melakukan cross chek kembali terkait obat-obat yang diresepkan oleh dokter-dokter spesialis sehingga tidak ada duplikasi golongan obat dan selalu memonitoring keadaan pasien.

Terlihat pada tabel 6, interaksi obat yang terjadi adalah pada obat dengan indeks terapi sempit, yaitu Digoxin dan Phenitoin. Obat-obatan yang mempunyai rentang terapi sempit lebih mungkin terlibat dalam interaksi obat yang bermakna secara klinis (Suprobo D.H, Siswanto B.B, dkk., 2011). Digoxin dan Kaptopril jika diberikan bersamaan dapat meningkatkan kadar serum digoxin dalam darah maksimal 20\% sehingga dapat menimbulkan salah satu efek toksik digoxin yaitu aritmia (Stockley, I.H., 2010). Pada penelitian ini, interaksi yang terjadi segera ditanggulangi dengan mengganti alternatif obat antihipertensi yaitu kandesartan sehingga efek samping tidak terjadi lebih lanjut.

Tabel 6. Interaksi Obat Aktual pada Pasien Strok

\begin{tabular}{|c|c|c|c|c|c|}
\hline No. & Nama Obat & & $\begin{array}{c}\text { Jumlah } \\
\text { Kasus }\end{array}$ & $\begin{array}{l}\text { Persentase } \\
(\%)\end{array}$ & Interaksi yang terjadi dan penanganan \\
\hline 1 & $\begin{array}{l}\text { Digoxin } \\
\text { Kaptopril }\end{array}$ & + & 1 & 1,25 & $\begin{array}{l}\text { Kaptopril dapat meninkatkan kadar digoksin } \\
\text { (hingga 20\%) sehingga meningkatkan efek } \\
\text { toksiknya yaitu aritmia. } \\
\text { Penanganan: captopril diganti dengan kandesartan }\end{array}$ \\
\hline 2 & $\begin{array}{l}\text { Phenitoin } \\
\text { Nimodipin }\end{array}$ & + & 2 & 2,5 & $\begin{array}{l}\text { Phenitoin dapat menurunkan kadar nimodipin } \\
\text { dengan mekanisme yang belum diketahui. } \\
\text { Efeknya tekanan darah pasien tidak mencapai } \\
\text { target yang diinginkan } \\
\text { Penanganan: meningkatkan dosis nimodipin }\end{array}$ \\
\hline 3 & $\begin{array}{l}\text { Kaptopril } \\
\text { Furosemid }\end{array}$ & + & 2 & 2,5 & $\begin{array}{l}\text { Penggunaan Kaptopril dan Furosemid secara } \\
\text { bersama dapat meningkatkan resiko hipokalemia } \\
\text { dan hiponatremia } \\
\text { Penanganan: memberikan suplemen kalium dan } \\
\text { natrium dengan dosis ganda (double dose) }\end{array}$ \\
\hline & Total & & 5 & 6,25 & \\
\hline
\end{tabular}

Phenitoin dan Nimodipin jika diberikan bersamaan dapat menurunkan kadar nimodipin dengan mekanisme yang belum diketahui, tapi mungkin karena kedua obat ini dimetabolisme pada isoenzim yang sama (Stockley, I.H., 2010). Saat penelitian ini dilakukan, pasien yang mendapatkan terapi phenitoin dan nimodipin secara bersama menunjukkan nilai penurunan tekanan darah yang tidak optimal. Target tekanan darah yang diinginkan adalah $<140 / 90 \mathrm{mmHg}$ namun tekanan darah pasien masih berkisar antara 150-160/100-110 mmHg. Usaha yang dilakukan dokter untuk mengoptimalkan terapi adalah dengan meningkatkan dosis nimodipin. Keputusan dokter untuk meningkatkan dosis ini berdasarkan rekomendasi dari apoteker. Apoteker melakukan perhitungan dosis terhadap kondisi individu pasien dengan mempertimbangkan fungsi organ lainnya seperti ginjal dan hati. Di Stroke Care Unit Rumah Sakit Pusat Otak Nasional, ditugaskan seorang apoteker klinis untuk memantau terapi pasien. Apoteker melakukan identifikasi permasalahan terkait obat pada pasien seperti misalnya potensi interaksi obat yang mungkin terjadi. Selanjutnya apoteker mendiskusikan temuannya kepada dokter 
berdasarkan literatur dan penelitian-penelitian terbaru (evidence based medication). Dokter di rumah sakit ini akan mempertimbangkan rekomendasi apoteker demi keselamatan pasien.

Interaksi obat aktual berikutnya adalah interaksi antara Kaptopril dan Furosemid. Kaptopril dan Furosemid bila diberikan bersamaan dapat meningkatkan resiko hipotensi, hipokalemia, dan hiponatremia karena penipisan volume cairan (Stockley, I.H., 2010). Pada penelitian ditemukan 2 pasien mengalami hipokalemia dan hiponatremia. Kedua pasien ini diberikan suplemen kalium dan natrium dengan dosis ganda untuk mengatasi permasalahan tersebut.

Usaha pencegahan dan penanganan yang tepat pada pasien strok yang mengalami interaksi obat telah dilakukan oleh dokter dan tenaga kesehatan lainnya di Rumah Sakit Pusat Otak Nasional. Usaha yang dilakukan tersebut dapat mengoptimalkan terapi pasien dan mengurangi reaksi obat yang tidak dikehendaki.

\section{SIMPULAN}

Berdasarkan hasil penelitian dapat disimpulkan bahwa tingkat kejadian interaksi obat aktual pada pasien strok di Rumah Sakit Pusat Otak Nasional adalah 6,25\%. Obat-obat yang berinteraksi adalah Digoksin dengan Kaptopril $(1,25 \%)$, Phenitoin dengan Nimodipin $(2,5 \%)$ dan Kaptopril dengan Furosemid (2,5\%). Penanganan yang tepat pada kejadian interaksi obat aktual telah dilakukan oleh klinisi di Rumah Sakit Pusat Otak Nasional sehingga pasien mendapatkan efek terapi yang optimal.

\section{DAFTAR PUSTAKA}

Alexander L.L,. 2011. Ischemic stroke. California: CME Resource.

Alhazzani W, Alshamsi F, Belley-Cote E, HeelsAnsdell D, Brignardello-Petersen R, Alquraini

M, et al. 2018. Efficacy and safety of stress ulcer prophylaxis in critically ill patients: a network meta-analysis of randomized trials. Intensive Care Med 44:1-11.

American Diabetes Association. 2015. Classification and Diagnosis of Diabetes
Mellitus. Diabetes Care 38(10):42-44.

Balitbang Kemenkes RI. 2018. Riset kesehatan dasar: RISKESDAS. Jakarta: Balitbang Kemenkes RI.

Bovim M.R, Askim T, Lydersen S, Fjaertoft H, Indredavik B. 2016. Complication in the first week after stroke: a 10-years comparison. BMC Neurology.

Bukhari S. 2017. Kajian interaksi obat pasien diabetes melitus tipe 2 ditinjau dari outcome terapi di rumah sakit angkatan laut DR. Mintohardjo. Skripsi: UIN Syarif Hidayatullah.

Bustamante A, Giralt D, Garcia-Berrocoso T, Rubiera M, Alvarez-Sabin J, Molina C, et al. 2017. The impact of post-stroke complication on in-hospital mortality depends on stroke severity. European Stroke Journal 2(1):54-63.

Dewi R.T.K, Siregar P, Alwi I, Rumende C.M. 2015. Pengaruh pemberian $N$ Acetylcysteine oral terhadap high sensitivity $C$ reactive protein $(H s-C R P)$ pada pasien hemodialisis kronis. Jurnal Penyakit Dalam Indonesia 2(4):228:232.

Ghani L, Mihardja L.K, Delima. 2016. Faktor risiko dominan penderita stroke di Indonesia. Buletin Penelitian Kesehatan 44(1):49-58.

Khalida H. 2015. Analisis potensi interaksi obat diabetes melitus pada resep obat pasien rawat jalan di RSAL Dr. Mintohardjo. Skripsi: UIN Syarif Hidayatullah Jakarta.

PERDOSSI. 2011. Pedoman penatalaksanaan stroke. Himpunan Dokter Spesialis Saraf Indonesia.

Putri L.E,. 2014. Studi penggunaan amlodipin pada pasien strokehemoragik. Skripsi: Universitas Muhammadiyah Malang.

Riyadina W dan Rahajeng E. 2013. Determinan Penyakit Stroke. Jurnal Kesehatan Masyarakat Nasional Edisi 7. 13:324-330.

Sacco R.L, Kasner S.E, Broderick J.P, Caplan L.L, Connors J.J, Culebras A, et al. 2013. 
An updated definition of stroke for the 21st century: A statement for healthcare professionals from the American Heart Association/American Stroke Asscociation. American Heart Association Journal 44:2064-2089.

Stockley, I.H. 2010. Stockley's Drug Interaction. Edisi 9. Great Britain: Pharmaceutical Press.
Suprobo D.H, Siswanto B.B, Yuniadi Y, Harimurti G.M. 2011. Intoksikasi digoksin: bagaimana cara mengenali dan penatalaksanaannya. Jurnal Kardiologi Indonesia 32:36-41.

Zulkarnaini A dan Martini R.D. 2019. Gambaran polifarmasi pasien geriatri di beberapa poliklinik RSUP Dr. M. Djamil Padang. Jurnal Kesehatan Andalas 8(1):1-6. 